\title{
THE HOUSING CONDITIONS IN BOSTON
}

\author{
By Robert Treat Paine, Esq.
}

Boston

The housing conditions of Boston may be studied under five aspects:

r. The growth of population compared with the increase of houses.

2. The facilities for the building of new houses by private enterprise.

3. The influence of philanthropic efforts in building model blocks and separate homes.

4. Building laws.

5. The diminution of slum conditions.

I. The following table has been prepared by Dr. E. M. Hartwell, statistician of Boston.

Population and Number of Dwelling-Houses with Per Cent of ANNUAL InCREase.

\begin{tabular}{c|c|c|c|c|c}
\hline Year & $\begin{array}{c}\text { Estimated } \\
\text { Population. }\end{array}$ & $\begin{array}{c}\text { Per Cent } \\
\text { Increase. }\end{array}$ & $\begin{array}{c}\text { Tutal Number } \\
\text { of Dwelling- } \\
\text { Houses. }\end{array}$ & $\begin{array}{c}\text { Per Cent } \\
\text { Increase. }\end{array}$ & $\begin{array}{c}\text { Of those } \\
\text { Vacant } \\
\text { Dwellings. }\end{array}$ \\
\hline I89 I & 457,772 & 2.07 & 53,429 & 2.42 & I I04 \\
I892 & 467,260 & 2.07 & 54,853 & 2.67 & 1,269 \\
I893 & 476,945 & 2.07 & 56,730 & 3.42 & 1,446 \\
I894 & 486,830 & 2.07 & 58,310 & 2.79 & I,866 \\
I895 & 496,920 & 2.07 & 60,039 & 2.96 & I,964 \\
I896 & 509,102 & 2.45 & 60,278 & .40 & 2,205 \\
I897 & 521,583 & 2.45 & 61,573 & 2.15 & 2,127 \\
I898 & 534,370 & 2.45 & 62,850 & 2.07 & 2,647 \\
I899 & 547,470 & 2.45 & 63,890 & 1.65 & 2,902 \\
I900 & 560,892 & 2.45 & 64,886 & 1.56 & 2,686 \\
I901 & 573,579 & 2.26 & 65,600 & r. I0 & 2,627 \\
\hline
\end{tabular}

In the ten years from $\mathrm{I} 89 \mathrm{I}$ to $\mathrm{I} 90 \mathrm{I}$, while the population increased from 457,772 to 573,579 , or 25.3 per cent, the number of dwelling-houses increased from 53,429 to 65,600 , or 22.8 per cent, not quite keeping pace; and though not a few of the new buildings

(123) 
are capacious tenement houses, yet actual conditions have probably not improved. It is to be noted that 4 per cent of the dwellings are vacant.

2. The facilities for the building of new houses in the suburbs steadily increase. The suburbs of Boston are deservedly healthy and are ample for a vast population.

The President of the Boston Elevated Railway Company has furnished the following statistics, which show in the last five and ten year periods a marvelous development and explain the exodus outward from the crowded centre into happy and healthy suburban life on some of the hundred hills which make these suburbs so attractive. This outward migration shows no sign of culmination, but is still under full headway.

The running time of the cars has improved so that it now averages nine miles per hour on the whole system, against six miles or less ten years ago when horses were used, and within the last five years it has been reduced about 8 per cent. The track mileage increased from 260 miles in 189 I to 296 in 1896 and 408 in $r 90 r$. "For the year ending September 30 , I89I, we ran 2,326,274 trips, $\mathrm{r} 7,462,572$ miles, carried II $9,264,40 \mathrm{I}$ revenue passengers and $8,466,3$ I I free transfer passengers. The average length of each trip at that time was 7.5 miles. Five years later we ran $\mathbf{2 , 8 2 2 , 1 4 2}$ trips, 25,84I,907 miles. carried $166,862,288$ revenue passengers and $\mathrm{r} 7,566,36 \mathrm{I}$ free transfer passengers. The average length of each trip was 9. I 6 miles. Five years later, or for the last fiscal year, we ran $3,883,737$ trips, $43,631,384$ miles, carried $2 \mathrm{I}_{3}, 703,983$ revenue passengers and $65,000,000$ free transfer passengers. The length of each trip had increased to I I.23 miles."

The co-operative bank system has greatly promoted the construction and separate ownership of the modest and cosy little homes springing up so rapidly in all the suburbs of Boston. The Pioneer Bank was started in 1877 , and to-day there are in Boston eighteen of these co-operative barks with a capital of $\$ 5,029,478$, nearly the whole of it loaned out on small estates. A score of years ago it was no easy matter to obtain a "building loan," but co-operative banks have perfected the system of loans to builders upon houses "in process of construction." The admirable process of small monthly payments not only educates the borrowers into habits of saving, but in a few years reduces the loan, so that the old-fashioned savings banks with their immense capital can take 
up at lower rates these loans, when they are reduced to the statute limit of 60 per cent of the value of the estate. Hence it is the case that the $\$ 5,000,000$ of co-operative bank capital by no means measures the full beneficial influence of this system in the growth of suburban homes.

3. The influence of philanthropic enterprise, compared with that of private business, has been insignificant.

Three incorporated societies are working in a small way, the oldest, the Boston Co-operative Building Company, chartered in I87 I. With a capital of $\$ 292,000$, it has about $\$ 400,000$ invested in seventy-eight houses with 985 rooms, occupied by 3 I I families containing $\mathrm{I}, 023$ persons.

The Harrison avenue group of twenty-four three-storied brick houses-each, except the corners, arranged for three families-has attracted deserved attention, with its hollow square in the centre, tastefully arranged as a playground for the children, and a bit of beauty for the parents.

The company has just started to reproduce this hollow square on its last purchase of 33,000 feet on Massachusetts avenue. Mr. A. W. Longfellow, the architect of the Harrison avenue group, furnishes this plan of a corner and a normal interior house just completed on Massachusetts avenue, showing the latest developments of model tenement house design, and also a land plan.

The thirty-one years of life of this company show many vicissitudes; 7 per cent being earned for some years, and then from 1876 to 1889 , dividends were stopped or reduced to 3 per cent and earnings were invested. Recently dividends have been 6 per cent or 5 per cent. But the capitalization of undivided profits has been so large, that it is not possible to ascertain what the just annual earnings are from year to year, and hence the educational influence is lost upon other capitalists who might be incited, by a clear and exact statement of facts, to follow the most commendable lead of this company in building the very best model tenements and having them managed by the considerate care of women agents.

The Workingmen's Building Association was organized in I888, to build small separate houses for sale. Its first purchase of 668,59 I feet, about three miles out in Roxbury, was most successful. This tract was divided into I 50 lots, averaging 4,457 feet, so that one acre has ten lots, with an estimated population of sixty to seventy souls. 


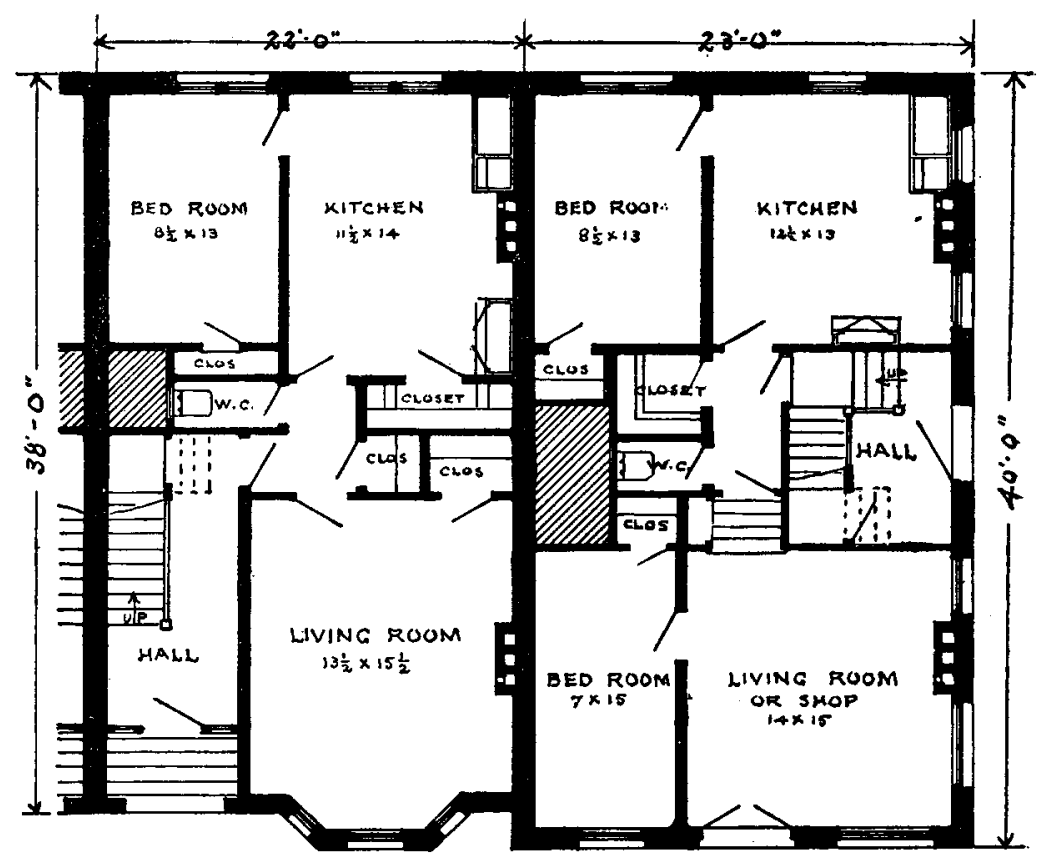

SECOND FLOOR LIVING ROOM

SECOND FLOOR LIVING ROOM $11 \frac{1}{2} \times 15 \frac{1}{2} \sim$ HALA BED ROOM $9 \times 10 \frac{1}{2} \quad 12 \frac{1}{2} \times 15 \sim$ BED ROOM $8 \frac{1}{2} \times 15$

FIRST FLOOR PLAN OF TWO HOUSES OF THE MASSACHUSETTS AVENUE BLOCK FOR THE BOSTON COÖPERATIVE BUILDING COMPANY -A.W.LONGFELLOW - ARCMITECT. 

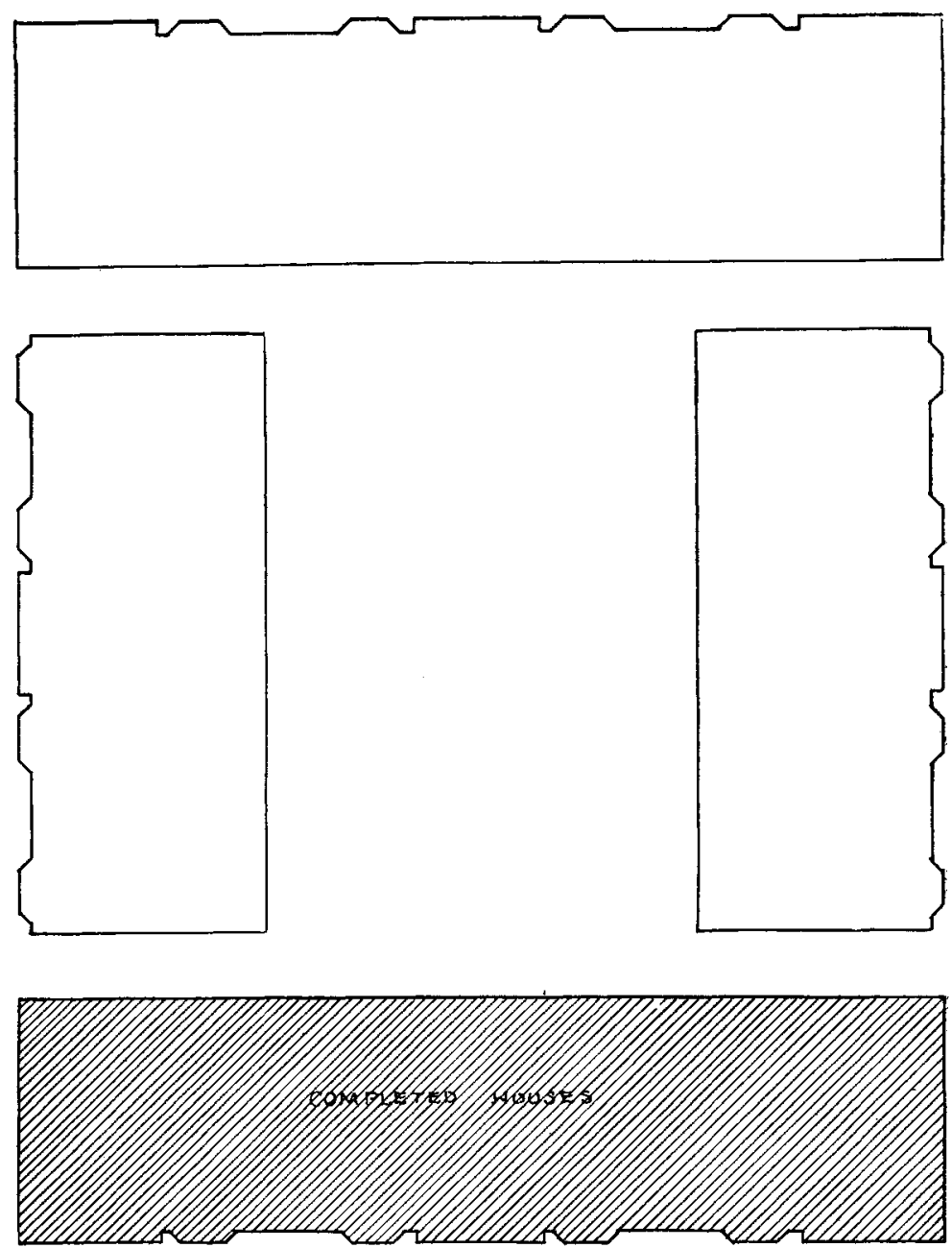

PLAN SMOWING ARRANGEMENT OF BLOCKS ON MASS, AVE, LUT[150\%200] AS PROPOSED FOR THE BOSTON CÖ̈PERATIVE BUILDING COMPANY W $\Psi$ \& A.W. LONGFELLOW.ARCHITECT- BOSTON- 
The houses cost from $\$ 1,800$ to $\$ 3,000$, and were almost all for single families, total cost of a house and land varying from $\$ 2,600$ to $\$ 4,500$. They were all sold by 1894 . Its next venture in Dorchester found the demand for single houses painfully reduced in the depression of the last seven years, while a marked preference shows itself for "two-family" or "three-flat" houses.

This company has not succeeded in building houses at lower cost, to its great regret.

4. The building laws of a city greatly influence results. Boston was startled by its great fire of 1872 into creating a stringent code. This was remodeled in 1885 , chapter 374. After a commission had studied the subject anew, the present code was enacted in 1892 , chapter 419 , with subsequent amendments.

Two features are especially important: (I), the percentage of the area of a lot which may be built upon; (2), the height of the buildings and the provisions as to fire-proof construction.

The law of $189^{2}$ permitted three-quarters of the area to be covered, measuring to the middle of the streets on which the lot abuts. This proviso, however, would allow a building to cover the whole of a lot sixty feet deep on a forty-foot street. The act also required two exposures on open spaces at least ten feet wide, of an aggregate length of one foot, for every twenty-five square feet occupied by the building.

These last provisions, however, were found not to prohibit the construction of a huge four-storied tenement house on a lot fortytwo feet wide and ror feet deep, built on a dumb-bell plan, with only about two feet of open land across a part, but not the whole, of the rear. It was the erection, in 1894 , of this barrack, which led many observers to doubt whether these new conditions were not worse than the old; whether these vast tenement houses, sometimes called model houses, were not far worse in many essentials for the health and welfare of their occupants than the little old houses, often built of wood, which they replaced. These views are confirmed by the deliberate judgment which Miss Octavia Hill has put on record in her valuable chapter in the second volume of Charles Booth's great work on London.

The construction of this great tenement house, with such trifling rear light, occasioned the act of 1895 , chapter 239 , which reduced the area to be occupied from 75 to 65 per cent, and also required an open space across the whole rear of the building, and 
of a depth equal to one-half the width of the front street, not exceeding twenty feet, or an equivalent area of open space in the rear of other dimensions.

The act of 1897 , chapter $4 \mathrm{I} 3$, section 9, exempts corner lots from this requirement of open rear land, and also gives the Building Commissioner discretion to accept "an equivalent area of open space in the rear or on either side of such building."

It is worthy of note that these requirements are less stringent than those in the new tenement house law, chapter 334, of I9or, for Greater New York, which limits the building to 90 per cent of a corner lot and 70 per cent of any other lot.

Secondly, the law of 1897 , chapter $4 \mathrm{I} 3$, section 3 , required every tenement house to be a first-class building, i. e., " of fireproof construction throughout." It was at once apprehended that this requirement, that all tenement houses must be of fireproof construction, would stop the building of tenement houses for tenants paying moderate rents. Subsequent investigation showed, that after existing permits had been exhausted, few, if any, tenement houses were built with tenements renting at $\$ 16$ a month or less. Reaction set in, and by the act of 1900 , chapter 321 , the requirement of fire-proof construction was removed from tenement houses of not more than four stories and not more than fifty feet in height, but here again came a proviso limiting these houses to "two families, or less, above the second story."

This is the present tenement house law of Boston. It seriously handicaps the construction of tenement houses, but whether this is too stringent, and the influences are harmful, is not yet apparent. So far as an impulse is given to scatter the population out into the healthier suburbs and into the small, separate, detached suburban homes, each with its little plot of land, instead of the fearful overcrowding of families in the huge new tenement houses, students of the social welfare of the people must certainly rejoice.

In the old North End of Boston, where population is densest and rentals are highest, the erection of new tenement houses and the remodeling of old buildings into tenement houses are visible in many of the streets. On the other hand, in the southerly part of old Boston, such enterprise is nearly at a standstill and rents are falling, owing probably to the greater attractiveness of the neighboring suburbs. 
The definition of a tenement house by the number of tenements, rather than by the number of rooms, discriminates with unintended harshness on just that class whose welfare ought especially to be studied, the very poor, the lone widow, the widower, the parent with a single child, who always find with difficulty a single spacious room, and usually pay higher rents because of the short supply of such much-needed accommodation. Twenty years ago a committee of the Associated Charities made a report to show the importance of building tenements of a single room and to call the attention of capitalists to this need. A small onestoried house with only four rooms, adapted for the needs of four separate women, must conform to all the expensive provisions of the tenement house code.

A just and judicious amendment should define a tenement house as having more than three tenements "and coniaining more than twelve rooms."

Workers among the poor were surprised last year at orders issuing from the Board of Health, for single tenants to vacate single rooms. Such a notice was nailed on the door of the large "square room" in the model block of the Boston Co-operative Building Company, on Canton street, occupied by a lone old woman. It is supposed that this mistaken policy has been abandoned.

A strange thing happened in 1892 ; the building law of that year, chapter $4 \mathrm{I} 9$, in its final section $\mathrm{r}_{3} 8$, repealing numerous laws, included a repeal of the health provision, 1885 , chapter 382 , section 4 , defining for health purposes a "tenement house." So that since I 892, the Board of Health has been shorn of so much of its powers over tenement houses as depended on the definition, so carefully inserted in the health law of 1885 , which has been since then the health code of Boston. Perhaps it is stranger still that no allusion can be found in the annual reports of the Board of Health, to this mysterious and probably unintended curtailment of health powers, the exact legal effect whereof no man can tell. ${ }^{1}$

2 The Board of Health, in their report for 1900 , (p. 40) say: "A tenement house in Massa. chusetts is one occupied by four or more families, while in New York it is one occupied by three families which was the law in Massachusetts until the statute was amended in 1894." This sentence is rich in blunders. No amendment was made in 1894 . The Health Act of 1885 . chapter 382 , section 4 , defined a tenement house as one with " more than three families." The Act of 1889 , chapter 450 , section 4, changed this to "more than two families." But the whole thing was repealed by 1892 , chapter $4 \mathrm{rg}$, section $\mathrm{I} 38$, so that since $\mathrm{r} 892$ there has been no definition at all of a tenement house in the health code of Boston. 
5. A crusade for the extirpation of the slums of Boston has been waged for the last fifteen years, thus far with no great success. Housing conditions are justly to be condemned so long as old, dilapidated and unsanitary buildings are allowed to stand, often so overcrowded upon the land that sunlight and air are practically shut out. Such conditions are a disgrace to any city. They tempt the most wretched of the poor, or vicious, or criminal classes to worse degradation. The bread-winner loses his health, which is his only wealth. Children grow up in shameless loss of self-respect. Frequent visitors are physicians, police officers, and charity agents; physicians to struggle with needless disease, the police to arrest criminals created by their foul environment, and charity agents to relieve countless varieties of want caused by cruel and unjust conditions of life.

Private initiative has been struggling in these years to secure more vigorous action by the Board of Health in the destruction of the worst slums. Prof. Dwight Porter, acting under the auspices of a voluntary committee, made an investigation and "Report upon a Sanitary Inspection of Certain Tenement-house Districts in Boston," in $\mathrm{r} 888$, which really started the movement.

Committees of the Associated Charities have lodged indictments against many vile slums and have been heard by the board. In $189 \mathrm{r}-2$, the state caused the Bureau of Labor to make a thorough and exhaustive investigation. The report of Hon. H. G. Wadlin sets forth in two volumes the results. (22d and $23 \mathrm{~d}$ Annual Reports of the Bureau of the Statistics of Labor. "A Tenement House Census of Boston," made pursuant to chapter I I 5, Resolves of $r 89 \mathrm{r}$.)

Sanitary conditions were classified under five heads: excellent, good, fair, poor, and bad. It may be truly stated that tenements falling so low as to be classed "bad" are so intolerable as to demand most summary measures for their destruction, yet $I, 346$ houses were found to deserve this just but terrible condemnation (Vol. r, p. 577).

"It may be safely assumed that whenever a tenement was designated as entirely bad as to its inside condition-that is, to be more explicit, was bad as to facilities for light and air, ventilation and cleanliness-such a tenement was unfit for human habitation. The existence of such tenements forms primarily an indictment against the landlord who is responsible for their condition. They 
should either be abandoned or improved. In some cases such improvement as would render them suitable for occupancy can easily be made; in other cases, no doubt, they should be permanently abandoned." (Vol. 2, p. 4I7.)

"The existence of defective outside sanitary conditions is, upon the whole, an indictment against the city; for while some of the defects are due to unclean or poorly kept private ways and alleys, the responsibility of the city for the existence of such defects can hardly be avoided." (Italics are the writer's.) (Vol. 2, p. 4I8.)

In the reports of the Boston Board of Health no allusion is found to this fearful indictment by the authorities of the Commonwealth, or to the following municipal report.

In 1895 a special committee of the Common Council was appointed to consider what improvement could be made in the tenement districts of Boston, and what legislation was needed. They made a very brief "Partial Report" (Document I 25 of I 895) from which may be quoted:- "In the North End the tenement houses are to-day a serious menace to public health. . . . The most astounding circumstance in connection with this investigation that attracted the attention of your committee is the social and financial standing of the owners of the most of these tenement houses."

In 1897 a study was made, under the direction of the Tenement House Committee of the Twentieth Century Club, of certain typical slums, and the results were published with plans of some seven areas where buildings were old, dilapidated and so overcrowded on the land, that no remedy was possible except destruction either of all or of many of the tenements. ("Some Slums in Boston," by H. K. Estabrook, May I 5, I898.)

A public hearing was granted by the Board of Health on June 27, 1898 , and many competent experts and real estate owners testified to the intolerable conditions. Mayor Quincy attended the hearing and promised strong support. Commendable progress was made in vacating or destroying some of the worst slums for about three years. But the exercise of the power to "destroy" seems recently to have been paralyzed, perhaps, as a result of pending litigation.

The law grants two powers to the Board of Health to deal with these evils. Since $185^{\circ}$, chapter 108 , tenements may be "vacated" if adjudged unfit for human habitation. This power should be exercised only after thorough investigation and on deliberate 
judgment, setting forth true and sufficient causes. It may easily work grave injury to owners if exercised unjustly. Yet, when justly exercised, orders to vacate should be adhered to and not lightly rescinded because of political or other pressure. Observe that this power to vacate requires no destruction of the building and cannot justly prevent use of the vacated tenement for other fit purposes, not of human habitation.

In 1897 , chapter 219 , the power to destroy [the statute word is "remove"] buildings first appeared in Massachusetts. Its origin is interesting. The British "Housing of the Working Classes Act," I 890 (53-54 Vict., chapter 70), sections 30-37, is the origin, so far as I know, of this new power "to order the demolition" of a "dwelling-house" "unfit for human habitation." Section $3^{8}$ enlarged this power and made it apply to "obstructive buildings," thus condemning one building because it injures another building. It is surprising that any American lawyer could suppose that such a power would be sustained in America, where the unlimited powers of the British Parliament are much curtailed by constitutional safeguards.

Yet New York soon copied this British Act ( 1895 , chapter $5^{6} 7$, amended by 1897 , chapter 57 ) in shape so condensed as to make its injustice more conspicuous. This act was enforced for a few years in the city of New York, till owners of property began to defend their rights in court. The suit of Dassori vs. the Health Department of New York has settled that this law cannot be enforced to its full extent.

"Proof that rear tenement houses, each five stories high, lighted only from a court on the west or front from five to eleven feet wide, and a space or opening of eleven inches wide at the southeast corner of the court, and a space on the east side of eight inches filled with all sorts of filth, occupied by II 5 persons, showing a death-rate almost twice the normal one, damp, filthy, infested with vermin, and filled with foul smells, and by their construction interfering with the light which would otherwise have been enjoyed by tenement houses on the front of the lots, justifies a finding that the rear tenement houses are unfit for habitation, but does not necessarily establish the fact that they are not capable of being made fit for other uses to which the owner might lawfully put them, nor does it show that the nuisance could not be abated in any other way than by their destruction. 
"The owner of a tenement house cannot be compelled to submit to its destruction, if it is on his own land, merely because some building adjacent to it is, by reason of its existence, deprived of proper ventilation." (N. Y. Health Dept. vs. Dassori, Appellate Division Reports, Vol. 2 I, p. 348. October, I 897.)

Boston deserves no credit for the slovenly shape in which this faulty law was reproduced, 1897 , chapter 2 I 9 , closely following the language of the New York act. First the power to vacate is set forth, yet while covering the same ground as our ancient and welltried statute (1 850, chap. 108; Pub. Sts., chap. 8o, sec. 24; Revised Laws, chap. 75, sec. 7I), neither repeals nor amends it. Then follows the power to order "removed," $i$. e., destroyed, a building irremediably "unfit for human habitation."

Statute I899, chapter 222 , enlarged these powers of the Board of Health so that the order may be not merely to "vacate" a building "unfit for human habitation," but to "cease to use" a building "unfit for use"; the power to order buildings destroyed remaining limited to those "unfit for human habitation."

The suit (October, I900) of Holland vs. Durgin et al. (Board of Health) has gone on appeal to the Supreme Court. It raises interesting questions as to this last statute, its constitutionality, the lawfulness of a decree to remove, without previous notice to or opportunity to be heard by the owner, as well as the lawfulness of an order to remove stables occupied by horses and sheds only for storage as "unfit for habitation" (sic), the statute language being "unfit for human habitation."

The Board of Health is thus clothed with transcendent powers, whose exercise vitally affects the physical and moral welfare, especially of that large portion of the people who are lowest in the economic scale. These powers should only be lodged in the hands of men of strong character, sound judgment, sanitary experience and genuine love for the plain people. Yet the action of the Boston Board of Health has been characterized for many years past by mysterious apathy.

The law provides that the Board of Health shall make annually "a full and comprehensive statement of its acts during the year, and a review of the sanitary condition of the city," yet in the annual volumes of the last ten years the space devoted to the sanitary condition of the city has been utterly insignificant.

"To this subject, houses vacated, nearly a whole page is 
devoted in the report for 1892 ; nearly two pages in the report for 1893 ; from four to six lines in each of the reports for I894, ' 95 , and ' 96 ; and not one word in the report for 1897 . Throughout the 122 pages of this last report, this extremely important duty to vacate houses unfit for occupancy is not mentioned.

"The report for 1895 says only this: "The number of houses which the board has ordered vacated during the year because of their unsanitary condition is II $\mathbf{2}$; of this number, however, a very large per cent were put in a satisfactory condition before the expiration of the time allowed the occupants to quit the premises, and in such cases the orders were not enforced.' The report for I 896 simply quotes this one sentence, word for word-except that 'I II' is substituted for 'I I 2.' This one sentence, then, is the 'full and comprehensive statement' of the acts of the three years, I 895-7."

In none of these reports since $\mathrm{I}_{92}$ "is a list given either of houses ordered vacated or of houses actually vacated, yet hundreds of other lists and tables are given, as lists of stables ordered discontinued, of passageways paved, and even of minor defects in certain houses. While in the reports of the New York Board of Health there are complete lists of houses vacated and of those demolished, in only two of "our reports, those for 1892 and '93, are any of the houses ordered vacated named."

The objection of injury to tenants by the destruction of slums has no weight. The Associated Charities (Report of 1898 , pp. 40-48) seized the occasion of the building of the South Station and the change in the neighborhood, in $1897-8$, to cause a careful study to be made of the results upon the welfare of the twelve poorest families known to them when that sudden and forced migration occurred. "It brought out the interesting fact that in every case the condition of the family was improved by the change."

Death-rates by wards are shown in the annual report of $I 9 \circ \mathbf{I}$ of the Registry Department of Boston for the first time, so that it is possible to compare. The ghastly fact stands out that the death-rate in some wards is more than double what it is in the healthier wards, viz: one person dying in the year 1900 out of 39 in Ward 7,40 in Ward $13,4 \mathrm{I}$ in Ward 6 , and 42 in Ward 5 , contrasted with one in $8 \mathrm{I}$ in Ward 25, 72 in Ward 24, $7 \mathrm{I}$ in Ward 23, 69 in Ward 20 (p. 5).

Now that this table proves how the murder of the innocents 
goes on, the public conscience should be aroused. Statisticians will also tell us that the ratio of sickness keeps pace with the ratio of death, so that sickness among the poor, with its train of evils, is twofold more than good sanitary conditions should tolerate.

The model buildings of London have told the world what a powerful influence upon the length of life (and of course upon the amount of sickness) of their occupants is exerted by healthy homes. The Peabody buildings with a population of about 20,000 show a death-rate of about $I$ in $7 I$; and the Waterlow buildings, with 30,000 tenants, about $\mathrm{I}$ in 100 , while the rate of all London is about $\mathrm{I}$ in 57 . In Boston, $\mathrm{I}$ out of 48 dies yearly.

A Tenement House Commission will probably be appointed by the Mayor this year, to consider and report upon existing conditions and possible improvement.

On the whole, the outlook is full of hope. Vigilance and vigorous action are demanded of all municipal authorities. Public interest is aroused. The action of other cities in Great Britain as well as in New York and other American cities warns Boston not to fall behind in this movement, which will surely give to us and our children a healthier city for the homes of the plain people, with its plague spots extirpated, and an increasing proportion of the population living out in suburban homes in this city of unsurpassed suburban beauty. 